\title{
Exploration and Analysis on Xi Jinping's Patriotism Educational Thoughts in the New Era
}

\author{
Qiu Hong Chao \\ Division of Human Resources, Lingnan Normal University, Zhanjiang, China
}

\section{Email address:}

cqiuhong@126.com

\section{To cite this article:}

Qiu Hong Chao. Exploration and Analysis on Xi Jinping's Patriotism Educational Thoughts in the New Era. International Journal of Education, Culture and Society. Vol. 4, No. 6, 2019, pp. 105-110. doi: 10.11648/j.ijecs.20190406.12

Received: November 13, 2019; Accepted: December 4, 2019; Published: December 10, 2019

\begin{abstract}
Based on the times and answering the questions of the Times, Xi Jinping's patriotic education thought in the new era has been formed and developed. Xi Jinping advocates that the patriotism is love of the Great Motherland, love of the Chinese nation, love of Chinese culture, love of the Communist Party of China, love of socialism with Chinese characteristics. He proposed that patriotism should be integrated into the education system of primary and secondary schools, and a unified educational system of "time", "degree" and "effect" should be constructed, so as to realize the Chinese dream of the great rejuvenation. Xi Jinping insists on the organic combination of patriotism and love of the Party, patriotism and love of socialism, patriotism and love of the world as the inherent characteristics of his patriotic education thoughts. Xi Jinping has greatly enhanced the spiritual realm and moral legitimacy of Chinese patriotic education ideological system in the new era. There are some important contributions, such as the rectification of the wrong ideological trend of patriotism education, the rational expression of Chinese paradigm, and the world's undertaking for the value orientation.
\end{abstract}

Keywords: Xi Jinping, Patriotic Education, New Era, Socialism with Chinese Characteristics

\section{Introduction}

Patriotism education is not only an important means to boost national spirits and enhance the cohesion force of a country, but also a necessary way to construct a modern country. Therefore, strengthening patriotism education is a key project for the socialism with Chinese characteristics in the new era. Xi Jinping, general secretary of the Central Committee of the Communist Party of China (CPC) and Chinese president, has attached great importance to patriotism education. Since the 18th National Congress of the Communist Party of China, he has made many important disclosures on patriotism education, emphasizing that "we should carry forward patriotism, and must regard patriotism education as an ever-lasting theme" and "patriotism education must run through the whole process of national education and spiritual civilization". As an important part of the socialist ideology with Chinese characteristics in the new era, Xi Jinping's patriotism education thought is the Chinese expression of the Marxist theoretical system of patriotism education, and is the theoretical and practical guideline for the implementation of patriotism education in the field of school education. In this sense, the comprehensive and in-depth exploration on $\mathrm{Xi}$ Jinping's patriotism education thoughts in the new era from the four dimensions, formation background, main connotation, inherent characteristics and theoretical contribution, has practical significance and theoretical value.

\section{Formation Background}

"A great era calls for great theories and breeds great theories. The age with magnificent changes, practices and development must be accompanied with extensive and profound theoretical innovation and thoughts creation." [1] under the historical background that the socialism with Chinese characteristics is undergoing new transformations, entering a new era, facing new challenges, completing new tasks, and embarking on a new journey, Xi Jinping has applied Marxism and socialist positions, viewpoints and methods to form and develop patriotism educational thoughts. 


\subsection{Formation in an Environment to Tackle Various Challenges in the Era with Economic Globalization}

$\mathrm{Xi}$ Jinping has formed the patriotism education thoughts in the new era under the harsh environment of dealing with the economic globalization-concerned challenges. It is well-known that one of the greatest characteristics of the current era is economic globalization, which is known as "an Alibaba's cave" and "a Pandora's box" and allows both opportunities and risks. To some extent, it has weakened the patriotism education in modern nation-states. On an individual level, economic globalization calls for a boundary-free global governance. The "earthman" discourse system advocated by economic globalization is dispelling people's cognition of patriotism education, thus leading to many people's doubts and puzzles about individual patriotic feeling, practice of serving one's motherland and the will of strengthening the motherland. Therefore, patriotism education has been strongly pinched by the "decentralization wall" of economic globalization. At the national level, in the context of economic globalization, national sovereignty has been constantly being eroded, national borders are becoming increasingly blurred, and patriotism education seemingly violates the "world trend". However, economic globalization is after all the competition of countries for economic interests. Only by ensuring the erectly standing sovereignty of a country can the stable foundation be guaranteed for the interests of the country and the people. Therefore, it is still of great significance to boost patriotism education. In the face of various situations, challenges and struggles brought about by economic globalization, Xi Jinping pointed out that we should see the general trend of world development in a comprehensive way, especially "should fully estimate the development and evolution complexity of the international landscape, the sharpness of international contradictions and struggles, the long-term nature of the vying in the international order, and the uncertainty in China's surrounding environment" [2]. On this basis, Xi Jinping, with the Marxist theoretical courage and calm thinking, has strongly suggested that patriotism education should not be weakened, but instead should be strengthened. In the 12th collective study session of the Political Bureau of the Central Committee of the Communist Party of China, Xi Jinping clearly emphasized that "through school education and other means, we should strengthen patriotism education and enhance the moral integrity and confidence of the Chinese". [3]

\subsection{Formation in the Pursuit of the Chinese Dream-the Great Rejuvenation of the Chinese Nation}

$\mathrm{Xi}$ Jinping has the patriotism educational thoughts formed in the pursuit of the Chinese Dream--the great rejuvenation of the Chinese nation. Ancient China had long taken its place in the front ranks of the world and created golden ages one after another in the long history. After the modern times, the Chinese nation had suffered various crises and hardships, and was plundered; and the people had been plunged into an abyss of misery. China has courageously forged forward in the dark, and never gave up. Realizing the great rejuvenation of the Chinese nation collectively embodies the long-cherished wish of the Chinese people in generations, and it is described as the greatest dream of the Chinese nation in modern times. Compared with the past, China in the new era for the construction of socialism with Chinese characteristics has better conditions, stronger power and greater determination to realize the great goal. However, Xi Jinping believes that the realization of the great rejuvenation of the Chinese nation relies on the effective implementation of patriotism education, which provides the motive force of development for the realization of the Chinese dream. "We must vigorously carry forward the great spirit of patriotism and provide a common spiritual support and a powerful spiritual drive for the Chinese dream of realizing the great rejuvenation of the Chinese nation." [4] Patriotism education is the main channel, main front and main force shaping individuals' spirits of patriotism, and then lay the inner foundation for the Chinese dream at the spiritual level. In return, the effective implementation of patriotism education also relies on the realization of the Chinese dream for continuous promotion and development. As Xi Jinping said: "We must lay a solid foundation for the common aspirations in adolescents with the Chinese dream, and educate and help the young to love our great motherland, our great people and our great Chinese nation forever." [5]

\subsection{Formation on the Basis of Cultivating and Promoting the Core Values of Socialism}

It has been on the basis of cultivating and promoting the core values of socialism that $\mathrm{Xi}$ Jinping formed the patriotism education thoughts in the new era. The core values are the coagulator for the stable development of society, the spiritual plinth for the healthy growth of national morality, and the concentrated reflection of the improved cultural soft power. With the unique charm of "replenishing the new age with the Chinese traditional cultures", the central collective leadership with $\mathrm{Xi}$ Jinping as the core has taken a broad and long-term view and creatively put forward the core values of socialism. "Patriotism", as a value criterion on the individual level, has been enlisted in the core values, and ranked the top. At the teacher-student symposium of Peking University, Xi Jinping pointed out: "A man must have moral integrity and human dignity. In the scope of either moral integrity or human dignity, patriotism is the first." [6] At the National Symposium on Cultural and Art Work, Xi Jinping emphasized that "in the core values of socialism, the deepest, most fundamental and most eternal is patriotism. Patriotism is a theme that is frequently mentioned and kept fresh." [7] Loving the country is an important part of the core values of socialism, making patriotism education a realistic manifestation of patriotic values in the educational world. In this sense, patriotism education has become indispensable in cultivating and promoting the core values of socialism. More importantly, patriotism education and socialist core values education complement each other. The former is a project simultaneously progressing with the cultivation and promotion of socialist core values. Xi Jinping said: "We must 
carry out in-depth, long-lasting and vivid patriotism education among the young while carrying forward and practicing the core values of socialism." [8] That is to say, we should carry out patriotism education and build a corresponding ideological system on the basis of cultivating and promoting the core values of socialism.

\section{Main Connotation}

\subsection{Educational Purpose of "Realizing the Rejuvenation"}

Regarding the purpose of patriotism education, Xi Jinping has advocated that patriotism education should focus on cultivating adolescent students with patriotic feeling, the behaviors of serving the country and the ambition of strengthening the country and finally guiding and condensing the patriotism of young students into the Chinese dream of realizing the great rejuvenation of the Chinese nation.

"Love for the motherland and the people is the deepest and most powerful emotion as well as the great love." [2] Cultivating young students to become rational patriots with patriotic feeling, the behaviors of serving the country and the ambition of strengthening the country is the direct purpose of education. However, the purpose of patriotism education cannot be limited to the cultivation of individual patriotic virtues, and should pursue social values that transcend personal characters. Patriotism education should be rooted in people's yearning of beautiful and happy life, and gather the great power for the great struggles, projects and undertakings of socialism with Chinese characteristics in the new era. In dealing with the advanced deeds of Comrade Huang Danian, $\mathrm{Xi}$ Jinping indicated that "we must incorporate patriotic feelings and the ambition of serving the country into the great cause of the reform and development of the motherland and into the people's great striving for creating create history, contributing wisdom and strength to realizing the 'Two Centenary Goals' and the Chinese dream of the great rejuvenation of the Chinese nation." [9] Xi Jinping also stressed at the teacher-student symposium of Peking University that "Patriotism should not merely be a slogan. It should be the close connection between individual aspirations and the future of the motherland and between individual lives and the destiny of the nation. It should be taking root in the people for the dedication to the country." [6] If "the Chinese dream of realizing the great rejuvenation of the Chinese nation is the distinct theme of contemporary Chinese patriotism" [8], fulfilling the Chinese dream becomes the ultimate goal of the patriotism education advocated by Xi Jinping in the new era.

\subsection{Educational Content of "Five Loves"}

Regarding the content of patriotism education, Xi Jinping expanded the basic connotation of "patriotism". He believes that the patriotism of the Chinese people is not only to love the great motherland in isolation, but also to love the Chinese nation, Chinese culture, the Chinese Communist Party and socialism with Chinese characteristics.

Patriotism education is not an abstract implementation of educational activities, but an educational practice carried out in the context of specific national systems. Therefore, talking about patriotism education in the context of China must be rooted in Chinese national culture with a view to the Chinese political system. The "nation" loved by "the patriotism education" in the Chinese context must include China as a state, the nation that constitutes the state, the culture that symbolizes the country, the leaders constructing the country, and the system for developing the country. Just to the point, $\mathrm{Xi}$ Jinping has suggested that "The Communist Party of China is the most determined promoter and practitioner of patriotic spirits. To carry forward patriotism, we must adhere to the unity of patriotism and socialism, safeguard the reunification of the country and national unity, and respect and inherit the history and culture of the Chinese nation". [4] At the 6th session of the Symposium on Tibet Work, Xi Jinping also proposed that we must constantly improve the state, national, cultural, political party and institutional identities in all ethnic groups. It is not difficult to see that training young students to love the great motherland, the Chinese nation, Chinese culture, the Chinese Communist Party and socialism with Chinese characteristics and attaching equal importance to the "five loves" has become the main content of Xi Jinping's patriotism education in the new era.

\subsection{Educational Method of "System Optimization"}

In terms of the methods for patriotism education, $\mathrm{Xi}$ Jinping has emphasized that patriotism education is a staged and integral task requiring collaborations, proposed to integrate patriotism in the education system of the primary and middle schools, colleges and universities, and advocated the optimization and unification of "time", "degree" and "effectiveness" to form a "systematically optimized" method system.

No matter how the significance, purpose and content of patriotism education are emphasized, in the long run, only by returning patriotism educational practice to the real education field can we fully release the true value of patriotism education. In the process of patriotism education practice, scientific and reasonable educational methods are indispensable. On the one hand, patriotism education is both a professional activity and a systematic project. It is not a specialized learning task accepted during a certain life period, but a moral cultivation activity running through people's whole life. $\mathrm{Xi}$ Jinping has pointed out that patriotism education is a practical activity that runs through the whole process of national education; it is necessary to develop a patriotism education system and mechanism that links primary and middle schools, colleges and universities, and to enhance the practical effects of patriotism education. On the other hand, a perfect patriotism educational system should be in line with the trend of the times (time), improve people's acceptance degree of patriotism education (degree), and pay attention to the effectiveness of teaching (effectiveness). Only by insisting on unifying the "time", "degree" and "effectiveness" of the education method can we optimize the 
overall effect of cultivating the patriotic feeling, the behavior of serving the country and the ambition of strengthening the country in young students. This is just as Xi Jinping said: "We must make full use of the great achievements of China's reform and development, the commemorative activities of major historical events, the patriotism education bases, the traditional Chinese festivals, and the state-level public memorial ceremonies to enhance the people's patriotic feelings and consciousness, and use various artistic forms and new media to vividly spread the spirit of patriotism." [4]

\section{Inherent Characteristics}

\subsection{Organic Combination of Patriotism and Loving the Party}

Adhering to the organic combination of patriotism education and love of the Chinese Communist Party is the first trait of Xi Jinping's patriotism education in the new era. Since the founding of the People's Republic of China in 1949 the Communist Party of China has been the core leader of the cause of socialism with Chinese characteristics. However, the core position of the leadership of the Communist Party of China is not an accidental fruit; instead, it is the choice of history, the people and practice. Xi Jinping believes that "Without the Communist Party, there would be no new China, not to mention the prosperity and strength of the new China. Sticking to the strong leadership core of the Chinese Communist Party is the fate of the Chinese nation." [2] Since the development of the country's future and destiny is bound together with the core leadership of the party in a common cause, patriotism means consciously accepting the leadership of the party, safeguarding the leadership of the party, and loving the party.

However, some erroneous views insist that patriotism can be separated from loving the party, and patriotism does not necessarily include loving the party. This is a highly biased view. The fate of the motherland and the destiny of the party are inseparable. As the core leader of the national liberation struggle and the development of the country's cause, the Communist Party of China has adhered to the fundamental purpose of serving the people, stayed true to the mission, and lead the people of all nationalities in the country to unite as one and work hard to make China achieve great world-renowned achievements. Therefore, patriotism cannot be separated from loving the party. It can even be said that "supporting and upholding the leadership of the Communist Party of China is an important indicator determining true patriotism" [10], patriotism education without loving the party is incomplete and untrue.

Furthermore, in the connotation of Xi Jinping's patriotism education in the new era, patriotism includes the love of the party, and the two are unified. In carrying forward and practicing the spirit of patriotism, the Chinese Communists have shouldered heavy responsibilities and sacrificed themselves for the national development and rejuvenation, and composed a magnificent chapter concerning the patriotic feelings, the behaviors of serving the country and the ambition of strengthening the country, being the most determined embracers and executors of patriotic spirits. Therefore, in the practice of education in primary and secondary schools, colleges and universities, it is necessary to organically integrate patriotism education and the love of the Chinese Communist Party.

\subsection{The Organic Combination of Patriotism and Loving Socialism}

Adhering to the organic combination of patriotism education and socialism is another trait of $\mathrm{Xi}$ Jinping's patriotism education in the new era. "There was a viewpoint that: Although I don't love socialism, I love the country. This view is untenable. For one loves no the socialist motherland, what kind of motherland would he love? The motherland is not an abstract Concept, but an entity composed of specific social forms and social systems." [11] Therefore, patriotism education must be based on a real state entity for the cultivation of the strong emotions and noble behaviors of loving and serving the country in young students.

$\mathrm{Xi}$ Jinping pointed out: "To carry forward the spirit of patriotism, we must adhere to the unity of patriotism and socialism. China's patriotism has always developed around the realization of national prosperity and the people's happiness, and finally converged to socialism with Chinese characteristics." [4] Contemporary China is a country with the socialist system, and insists on taking the political development path of socialism with Chinese characteristics. It has been demonstrated by history and practice that China's socialist democracy has a strong vitality, and the political development path of socialism with Chinese characteristics is the correct way according with China's national conditions and guaranteeing the national master role of the people. [2] In other words, it is only the political development road of socialism with Chinese characteristics, rather than any other roads, that can lead the development and progress of Chinese society and realize the Chinese dream of the great rejuvenation of the Chinese nation. In a word, socialism is the institutional expression and the inevitable choice of today's China today. Patriotism requires conscious safeguarding the socialist system, and should be organically integrated with loving socialism.

\subsection{The Organic Combination of Patriotism and Loving People World Wide}

Adhering to the organic combination of patriotism education and love for all human beings is the third trait of $\mathrm{Xi}$ Jinping's patriotism education in the new era. Patriotism education aims to cultivate young students' loyalty to and recognition of their country and their willingness of contributing to the prosperity, strength and flourishing of the country. However, the result is not an over-inflated patriotic feelings and behaviors, a narrow national chauvinism, and a consequent neglect of or hostility to other countries, which might harm or invade the interests of other nations. 
Patriotism education is rational patriotic practices to realize the common interests of all countries. It is conducive to building a share community in politics, economy, security, civilization and ecology for all human beings.

Xi Jinping pointed out: "To carry forward the spirit of patriotism, we must adhere to the nationality and face the world." [4] Therefore, patriotism education should have international horizon, global thinking, world vision and universal concepts on the foundation of nation and state-embedded political, overall, core and calibration consciousness. In response to the question of how patriotism education faces the world, Xi Jinping put forward that "In today's world, countries are interdependent and share weal and woe together. We should build a community with a shared future for mankind." [2] The concept of a community with a shared future for mankind can be said to be an important guiding principle of $\mathrm{Xi}$ Jinping's patriotism educational thoughts in the new era, fully demonstrates the international leadership, value rationality and practical morality of patriotism education, and seeks the pluralistic symbiosis of all human beings. With the philosophy of a community with a shared future for humankind, Xi Jinping called on the people of all countries in the world to treat each other on an equal footing, seek for peaceful development, jointly construct the world, share the achievements, work together for win-win outcomes, maintain harmony in diversity and be inclusive for mutual benefits. In the process of school education practice, the organic combination of patriotism education and love for all human beings is the fundamental manifestation of deepening the value orientation of patriotism education thoughts.

It can be simply found that Xi Jinping has been standing at the development forefront of the times, holding the noble disposition of keeping a foothold in the country and having the whole world in view, showing the orientation of combining patriotic feelings and human undertaking, using the broad vision of Marxism and socialism to analyze patriotism in all directions, and insisting on the organic combination of patriotism and love of the party/socialism/all human beings, to shape the inherent characteristics of $\mathrm{Xi}$ Jinping's patriotism education in the new era.

\section{Theoretical Contribution}

\subsection{Reform the Wrong Ideological Trend of the Patriotism Education}

In the context of globalization, vigorously advocating patriotism education has the effect of clearing the source of false thoughts and rectifying the chaos, which is the primary theoretical contribution of Xi Jinping's patriotism in the new era.

Is patriotism education necessary in the context of economic globalization? Answering it is the premise and foundation for constructing the theoretical system of patriotism education in the new era and promoting the practice of patriotism education in the new era. There are some erroneous thoughts declaring that economic globalization will inevitably lead to the end of the national sovereignty theory, and patriotism education will eventually die out. The misunderstandings with the cover of historical nihilism or national nihilism have ulterior motives to preach the superiority of human rights over sovereignty, weaken people's sense of national sovereignty, downplays patriotism education in schools, and ultimately leads to the strengthening of patriotism education into a meaningless thing. Targeting the historical nihilism and national nihilism breed in the context of economic globalization, Xi Jinping has kept a foothold of the Marxist views of history, the state and the culture, clearly opposed historical nihilism and national nihilism, vigorously advocated patriotism education, clearly proposed the value, position, purpose, content and methods of patriotism education, fostered the awareness of the Chinese nation community, and enhanced the senses of belonging, identity and dignity of the Chinese nation. This has radically reformed the wrong ideological trend of patriotism education, and enables the top-level design for the effective implementation of patriotism education.

Undoubtedly, patriotism is the theme that should be promoted in any era, and patriotism education is a practical activity that should be advocated in any era. Under the background of economic globalization, Xi Jinping has made great contributions to cultivating the patriotic feelings, the behaviors of serving the country and the ambition of strengthening the country in young students in the new era and to innovating and developing the theoretical system of socialist patriotism education.

\subsection{Rational Expression of Chinese Paradigm in Patriotism Education}

Adhering to unity of "loving the great motherland, the Chinese nation, Chinese culture, the Chinese Communist Party and Socialism with Chinese Characteristics" and exploring the patriotism education paradigm that highlights the Chinese road, spirit, style, concept and quality is a special theoretical contribution of Xi Jinping's patriotism education in the new era.

$\mathrm{Xi}$ Jinping's patriotism educational thoughts is rooted in the Chinese soil and formed and developed in the historical practice of contemporary China. Being a rational expression of the Chinese scheme for patriotism education in the new era, it has vivid Chinese characteristics and style. In particular, the organic unification of patriotism, love for the party, socialism and all human beings has enhanced the confidence of socialist roads with Chinese characteristics, the self-confidence in the theories, the institution and the culture, and deepened the connotation of the Marxism and socialist patriotism education ideological system, being the spiritual guidance for the Chinese dream of realizing the great rejuvenation of the Chinese nation.

As a Chinese paradigm, Xi Jinping's patriotism education in the new era perfectly agrees with China's basic national conditions and cultural characteristics, and is bound to be the theoretical program and action guide for implementing 
patriotism education and education reform and development in school education. The rational expression of the Chinese paradigm of patriotism education guides contemporary Chinese patriotism education to practice new directions, goals and connotations, and contributes a new paradigm, pattern and method patriotism education in other countries.

\subsection{The World's Undertaking for the Value Orientation of Patriotism Education}

Rooting in the family-country feelings while opening up the world's vision, focusing on patriotic responsibility for the enlightenment of the global consciousness, incorporating the construction of a community of shared destiny for human beings into patriotism education, enriching the value orientation of socialist patriotism education with international visions and undertakings is an important theoretical contribution of Xi Jinping's patriotism education thoughts in the new era. "Human beings are increasingly becoming a community of shared destiny interwoven with each other." [5] $\mathrm{Xi}$ Jinping's new-era patriotism based on the consciousness of a community of shared destiny for human beings has pioneered the example of combining patriotism with internationalism, upgraded the spiritual realm of patriotism education, and contributed Chinese wisdom to the world's peace and development. The world's undertakings of the values in patriotism education has abandoned "bossy" patriotism education thoughts, and adhering to the patriotism education concept of "benevolent government". It subjects the national development and the destiny of the world to the common control of all countries, and thus creates a lasting peaceful, jointly thriving, beautiful and harmonious world.

Furthermore, the value orientation of world's undertakings in Xi Jinping's patriotism education in the new era has shown that China's mission of promoting world peace and development will not change and China's determination in safeguarding world peace and development will not change, which then completely smashes the paradox of "China threat theory" and establish a Chinese image of loving peace, never seeking hegemony, being courage to take responsibility, and pursuing humanity.

\section{Conclusion}

In conclusion, with the theoretical creativity and profound insight of Marxist thinkers, Xi Jinping has put forward patriotism education with unique temperament and theoretical quality in the new era. Based on the four dimensions of background, main connotation, inherent characteristics and theoretical contributions, the paper comprehensively dissects $\mathrm{Xi}$ Jinping's patriotism education ideology in the new era, and then provides support for deep and scientific understanding and comprehensive implementation of Xi Jinping's socialist ideology with Chinese characteristics. The analysis on Xi Jinping's patriotism education thought in the new era is conducive to recognizing the essence of $\mathrm{Xi}$ Jinping's patriotism education ideology and to the correct, scientific and effective development of patriotism education in primary and secondary schools, colleges and universities, consequently consolidating the foundation for effectively cultivating the awareness of "a community of shared destiny for the Chinese nation" and realizing the Chinese dream of the great rejuvenation of the Chinese nation.

\section{References}

[1] Publicity Department of the CPC Central Committee, Xi Jinping's Thought on Socialism with Chinese Characteristics for a New Era (Lecture 30). Beijing: Learning Press, 2018, pp. $1-5$.

[2] Jin-Ping XI, Xi Jinping: The Governance of China, vol. 2. Beijing: Foreign Languages Press, 2017, pp. 288-522.

[3] Jin-Ping XI, Xi Jinping on Patriotism-Excerpts from Important Discussions since the 18th National Congress. Development of the Party, Vol. 29, No. 2, 2016, pp. 4-6.

[4] Jin-Ping XI, Vigorously Promote the Great Spirit of Patriotism to Provide Spiritual Support for the Realization of the Chinese Dream. People's Daily, December 31, 2015.

[5] Jin-Ping XI, Xi Jinping: The Governance of China. Beijing: Foreign Languages Press, 2014, p53, p272.

[6] Jin-Ping XI, Speech at the Forum between Teachers and Students of Peking University. People's Daily, May 2, 2018.

[7] Commentator, Patriotism is always a New Topic. Literature and Art Daily, November 7, 2016.

[8] Jin-Ping XI, Let Patriotism Firmly Root in the Hearts of Young People. China Education Daily, December 31, 2015.

[9] Jin-Ping XI, Xi Jinping Made Important Instructions to Comrade Huang Danian's Advanced Deeds. People's Daily, May 26, 2017.

[10] Ze-Ying Wang, Research on Xi Jinping's Patriotism in the New Era. Studies in Ethics, Vol. 17, No. 2, 2018, pp. 1-7.

[11] Xiang-Yang XIN, An Analysis of Xi Jinping's Patriotism Thought. Journal of Hangzhou Party School of the CPC, Vol. 17, No. 1, 2016, pp. 4-8. 